\title{
Drug reaction with eosinophilia and systemic symptoms after daclizumab therapy in MS
}

Franziska Scheibe, MD, Imke Metz, MD, Helena Radbruch, MD, Eberhard Siebert, MD, Stefan Wolf, MD, Martin Köhnlein, MD, Lutz Harms, MD, and Andreas Meisel, MD

Neurol Neuroimmunol Neuroinflamm 2018;5:e479. doi:10.1212/NXI.0000000000000479
Correspondence

Dr. Scheibe

franziska.scheibe@charite.de

\section{Case report}

In 2012, a 33-year-old woman was diagnosed with relapsing-remitting MS (RRMS) after fulfilling McDonald criteria and careful exclusion of other differential diagnoses. Five years later (EDSS 1), she changed her disease-modifying therapy after side effects to betaferon (flu-like symptoms) and dimethyl fumarate (erythema and pruritus) to daclizumab. Two months after 2 applications of $150 \mathrm{mg}$ daclizumab, she developed a self-limiting rash (figure 1A), followed by fever, headaches, meningismus, photophobia, nausea, paraesthesia, and itching of her upper body 1 month later. Blood test showed decreased lymphocyte counts of $1.7 / \mu \mathrm{L}(17.1 \%)$ and increased eosinophil granulocytes of $1.5 / \mu \mathrm{L}(15.1 \%)$. CSF analysis revealed pleocytosis of 570/ $\mu \mathrm{L}(1.8 \%$ eosinophilic granulocytes) and an initially negative, but 2 weeks later marked intrathecal immunoglobulin synthesis (IgM 85\%, IgA 43\%, and IgG 38\%). MRI showed periventricular contrast-enhancing lesions and a multisegmental cervical myelitis (C1-4). After 10 days, she further deteriorated by severe infratentorial edema with compression of the fourth ventricle and obstructive hydrocephalus (figure 1, B-F). At admission to our hospital, she obtained an external ventricle drainage showing normal opening pressure. Two days later, she had sudden increase in intracranial pressure requiring intubation and emergency decompressive surgery of the posterior fossa. Increased intracranial pressure (up to $40 \mathrm{~mm} \mathrm{Hg}$ ) due to global brain edema and subsequently complicated by a postoperative bleeding into the right frontal lobe after a brain biopsy (see below) was controlled by CSF drainage, deep analgosedation, dexamethasone, and osmotherapy. The atypical clinical picture with brain edema, rhombenecephalitis, and high CSF cell count was incompatible with MS relapse as initially suggested by the periventricular lesions and cervical myelitis. Because careful examinations revealed no other autoimmune or infectious diseases, we initially treated polypragmatically with aciclovir/ganciclovir, ceftriaxone/ampicillin, voriconazole/posaconazole, and IV immunoglobulins. Brain biopsies of the right frontal lobe, cerebellum, and cerebellar leptomeninges showed inflammatory demyelinating lesions with pronounced inflammation, numerous $\mathrm{T}$ cells, eosinophils, plasma cells, and an eosinophilic and lymphoplasmacellular meningitis (figure 1, G-J). We diagnosed the patient with CNS manifestation of daclizumab-induced DRESS (drug reaction with eosinophilia and systemic symptoms) since 6 of 7 Registry of Severe Cutaneous Adverse Reaction Criteria (RegiSCAR) ${ }^{1}$ for DRESS were fulfilled (positive: hospitalization, reaction suspected to be drug-related, fever $>38^{\circ} \mathrm{C}$, skin rash, internal organ involvement, blood eosinophilia; negative: lymphadenopathy). Accordingly, the patient was treated with high-dose IV methylprednisolone ( 5 days with $1 \mathrm{~g}$ each) and 6 cycles of plasma exchange, followed by 1 $\mathrm{mg} / \mathrm{kg}$ oral prednisolone with subsequent tapering. Thereafter, the patient improved dramatically and could be extubated 2 weeks after disease exacerbation. Postoperative disease course was complicated by wound infection, bacterial meningitis, persisting CSF effusion, and

From the Department of Neurology (F.S., M.K., L.H., A.M.), Charité-Universitätsmedizin Berlin; Institute of Neuropathology (I.M.), Universitätsmedizin Göttingen, Göttingen, Germany; Institute of Neuropathology (H.R.), Charité-Universitätsmedizin Berlin, Institute of Neuroradiology (E.S.), Charité-Universitätsmedizin Berlin; Department of Neurosurgery (S.W.), Charité-Universitätsmedizin Berlin; NeuroCure Clinical Research Center (A.M.), Charité-Universitätsmedizin Berlin; and Center for Stroke Research Berlin (F.S., A.M.), Charité-Universitätsmedizin Berlin, Germany.

Funding information and disclosures are provided at the end of the article. Full disclosure form information provided by the authors is available with the full text of this article at Neurology.org/NN.

The Article Processing Charge was funded by Charité-Universitätsmedizin Berlin.

This is an open access article distributed under the terms of the Creative Commons Attribution-NonCommercial-NoDerivatives License 4.0 (CC BY-NC-ND), which permits downloading and sharing the work provided it is properly cited. The work cannot be changed in any way or used commercially without permission from the journal. 

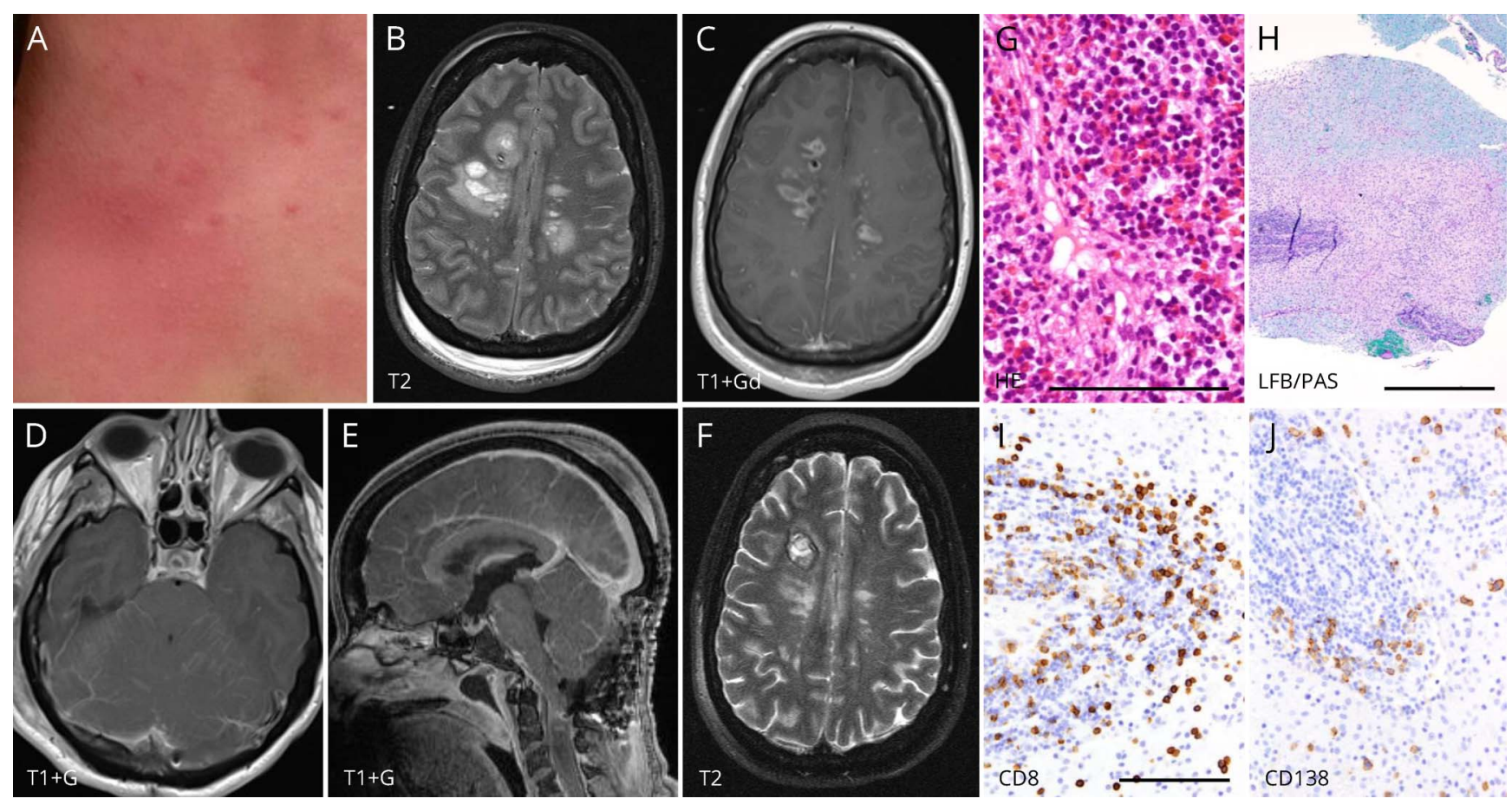

(A) Skin rash of the neckline. (B and C) MRI shows multiple actively contrast-enhancing MS-like lesions with distinct perifocal edema. (D and E) Additionally diffuse cerebellar edema is present accompanied by infratentorial leptomeningeal enhancement indicative of meningeal and cerebellar inflammation. Resulting mass effect and occlusive hydrocephalus required suboccipital decompression (E). Also note simultaneous cervical cord inflammatory lesion. ( $\mathrm{F}$ ) Complete resolution of perifocal edema after disease remission. Note the right frontal hemorrhagic biopsy defect. (G-J) Biopsies of cerebellar meninges (G) and a right frontal lesion $(\mathrm{H}-J)$ show a pronounced inflammatory infiltrate. HE staining depicts meningitis with numerous T cells, plasma cells, and eosinophilic granulocytes (G). Histology of the right frontal lesion reveals a demyelinated lesion (H). Again, dominant inflammation, consisting of CD4- and CD8-positive T cells (I, anti-CD8), CD138-positive plasma cells (J, anti-CD138), and eosinophilic granulocytes, is evident. Inflammatory cells densely infiltrate vessel walls, resembling vasculitis. In addition, pronounced parenchymal inflammation is evident. $\mathrm{HE}=$ hematoxylin/eosin, LFB/PAS = luxol fast blue/periodic acid-Schiff. Scale bars: $\mathrm{G}=100 \mu \mathrm{m}, \mathrm{H}=1 \mathrm{~mm}$, and I (valid for I and J) $=200 \mu \mathrm{m}$.

obstructive hydrocephalus that required a ventriculoperitoneal shunt. Four months later, neurologic syndromes with tetraparesis, choreoathetosis, cerebellar ataxia, and cognitive dysfunctions had regressed substantially (EDSS 3.5).

\section{Discussion}

Daclizumab is approved for RRMS therapy since it revealed efficacy by reducing relapse rates and MRI lesion load. ${ }^{2}$ It binds to the interleukin- 2 receptor and leads to reduction of activated $\mathrm{T}$ cells and regulatory $\mathrm{T}$ cells and expansion of natural killer cells. ${ }^{3,4}$ Common daclizumab side effects comprise infections (59\%), cutaneous (33\%), gastrointestinal (25\%), and hepatic disorders $(16 \%) .{ }^{5}$ Until recently, no persuasive evidence of DRESS existed in daclizumab-treated patients, ${ }^{5}$ especially not with CNS manifestation. Several drugs including immunomodulators can trigger DRESS presenting with skin eruption, hematologic abnormalities, lymphadenopathy, and internal organ involvement. ${ }^{6}$ DRESS usually develops with a latency of 2 to 12 weeks after drug exposure showing often a prolonged course and can be lethal in $\sim 10 \%$ of cases. The pathogenesis of DRESS remains unclear, but reactivation of herpesviridae and pharmacogenomic association with certain human leukocyte antigen haplotypes may cause the increased susceptibility to
DRESS and its associated drug-specific immune dysfunction. ${ }^{6}$ CNS DRESS is extremely rare and typically presents with a vasculitis-like pattern.?

Core symptoms of our patient comprised fever, skin rash, blood eosinophilia, and eosinophilic meningoencephalomyelitis. We diagnosed our patient with daclizumab-induced DRESS with CNS manifestation since a recent publication presented 2 further cases of daclizumab-induced DRESS in MS. ${ }^{8}$ In line with our case, these patients showed similar clinical symptoms, fulfilled RegiSCAR criteria of DRESS, and were characterized by the same unique histopathologic findings with demyelinating lesions consisting of lymphoplasmacellular and eosinophilic infiltrates and a vasculitic-like pattern. Other differential diagnosis like parasitosis or neuromyelitis optica (NMO) was excluded. NMO can show eosinophilic infiltrates in demyelinating lesions, but further NMO characteristics like aquaporin-4 loss, dystrophic astrocytes, or loss of oligodendrocytes were missing, and aquaporin-4 antibody testing was negative in our patient. Although DRESS criteria were formally fulfilled, it remains open whether DRESS alone best explains pathophysiology or whether other/further mechanisms are involved in daclizumab-induced immune dysfunction. In contrast to 
regular DRESS that barely affects the CNS, daclizumabinduced DRESS seems to occur predominantly within the CNS. The cause of this idiosyncratic drug reaction remains speculative, but a certain genetic, viral, and autoimmune susceptibility in the context of MS has to be considered. At least, a viral association (human herpes virus-6, cytomegalovirus, and Epstein-Barr virus) of DRESS was excluded in our case.

Currently, 12 cases (including our patient) of autoimmune encephalitis/encephalopathy after daclizumab therapy in MS are known worldwide and led to voluntary withdrawal of marketing authorization for daclizumab by the manufacturer Biogen (press release from European Medicines Agency, 07.03.2018). ${ }^{9}$

Our findings suggest that early recognition of DRESS even with CNS manifestations and swift treatment with steroids and/or plasma exchange are essential to improve the longterm outcome.

\section{Author contributions}

F. Scheibe: patient care, data acquisition, analysis and interpretation of data, and writing of the manuscript. I. Metz and $H$. Radbruch: histopathologic analysis and writing of the manuscript. E. Siebert: neuroradiologic interpretation of data and writing of the manuscript. S. Wolf and M. Köhnlein: patient care and writing of the manuscript. L. Harms: critical revision of the manuscript for intellectual content. A. Meisel: patient care, writing of the manuscript, and critical revision of the manuscript for intellectual content.

\section{Acknowledgment}

The authors thank the patient for participation in the study.

\section{Study funding}

The authors acknowledge support from the Open Access Publication Fund of Charité-Universitätsmedizin Berlin.

\section{Disclosure}

F. Scheibe reports no disclosures. I. Metz served on the advisory board of Roche; received speaker honoraria and travel grants from Biogen Idec, Bayer Healthcare, Teva, Merck Serono, Novartis, and Genzyme; and received research support from Biogen Idec and German Ministry of Education and Research. H. Radbruch received travel funding and/or speaker honoraria from Novartis and Sanofi and received research support from Novartis, Sanofi, and Deutsche Forschungsgemeinschaft. E. Siebert, S. Wolf, and M. Koehnlein report no disclosures. L. Harms serves on the advisory board of Novartis, Sanofi/Genzyme, Roche, and Biogen and received speaker honoraria and/or travel funding from Biogen, Merck Serono, Genzyme, Teva, Bayer Healthcare, Novartis, and Grifols. A. Meisel received speaker honoraria from Alexion and Grifols; served on the editorial board of PLoS One, Journal of Cerebral Blood Floow \& Metabolism, and BMC Neurology; consulted for Alexion and Deutsche Myasthenie Gesellschaft; served on the speakers' bureau of Frau Schneider GmbH; and received research support from Octapharma and Deutsche Forschungsgemeinschaft NeuroCure Cluster of Excellence and Collaborative Research Centers and Bundesministerium für Bildung und Forschung Center for Stroke Research Berlin. Full disclosure form information provided by the authors is available with the full text of this article at Neurology.org/NN.

Received March 19, 2018. Accepted in final form May 29, 2018.

\section{References}

1. Kardaun SH, Sidoroff A, Valeyrie-Allanore L, et al. Variability in the clinical pattern of cutaneous side-effects of drugs with systemic symptoms: does a DRESS syndrome really exist? Br J Dermatol 2007;156:609-611.

2. Kappos L, Wiendl H, Selmaj K, et al. Daclizumab HYP versus Interferon Beta-1a in relapsing multiple sclerosis. N Engl J Med 2015;373:1418-1428.

3. Bielekova B, Catalfamo M, Reichert-Scrivner S, et al. Regulatory CD56(bright) natural killer cells mediate immunomodulatory effects of IL-2Ralpha-targeted therapy (daclizumab) in multiple sclerosis. Proc Natl Acad Sci U S A 2006;103:5941-5946.

4. Elkins J, Sheridan J, Amaravadi L, et al. CD56(bright) natural killer cells and response to daclizumab HYP in relapsing-remitting MS. Neurol Neuroimmunol Neuroinflamm 2015;2:e65. doi: 10.1212/NXI.0000000000000065.

5. Giovannoni G, Kappos L, Gold R, et al. Safety and tolerability profile of daclizumab in patients with relapsing-remitting multiple sclerosis: an integrated analysis of clinical studies. Mult Scler Relat Disord 2016;9:36-46.

6. Cacoub P, Musette P, Descamps V, et al. The DRESS syndrome: a literature review. Am J Med 2011;124:588-597.

7. Gaha M, Landry D, Bélair M, Paquet B, Chapdelaine H, Bard C. DRESS syndrome: cerebral vasculitic-like presentation. Neuroradiology 2015;57:1015-1021.

8. Rauer S, Stork L, Urbach H, et al. Drug reaction with eosinophilia and systemic symptoms after daclizumab therapy. Neurology 2018. Epub ahead of print.

9. Press release by the European Medicines Agency (EMA): multiple sclerosis medicine Zinbryta suspended in the EU. In: EMA Homepage [online]. Available at: ema. europa.eu/ema/index.jsp?curl=pages/medicines/human/referrals/Zinbryta/human_ referral_prac_000074.jsp\&mid=WC0b01ac05805c516f. Accessed March 7, 2018. 


\section{Neurology \\ Neuroimmunology \& Neuroinflammation}

Drug reaction with eosinophilia and systemic symptoms after daclizumab therapy in MS

Franziska Scheibe, Imke Metz, Helena Radbruch, et al.

Neurol Neuroimmunol Neuroinflamm 2018;5;

DOI 10.1212/NXI.0000000000000479

This information is current as of July 10, 2018

Neurol Neuroimmunol Neuroinflamm is an official journal of the American Academy of Neurology.

Published since April 2014, it is an open-access, online-only, continuous publication journal. Copyright

Copyright (C) 2018 The Author(s). Published by Wolters Kluwer Health, Inc. on behalf of the American

Academy of Neurology.. All rights reserved. Online ISSN: 2332-7812.

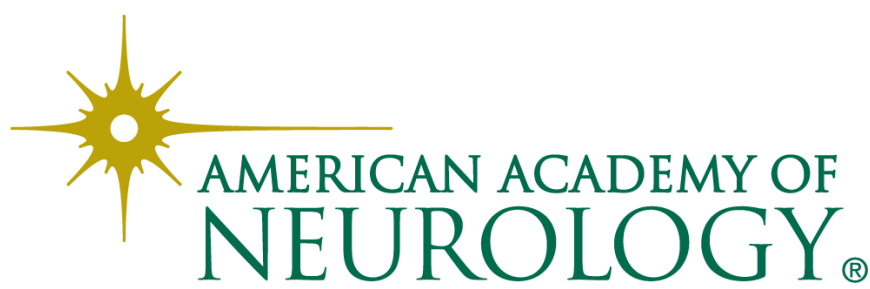




\section{Updated Information \& Services}

References

Citations

Subspecialty Collections

Permissions \& Licensing

Reprints including high resolution figures, can be found at: http://nn.neurology.org/content/5/5/e479.full.html

This article cites 7 articles, 1 of which you can access for free at: http://nn.neurology.org/content/5/5/e479.full.html\#\#ref-list-1

This article has been cited by 3 HighWire-hosted articles: http://nn.neurology.org/content/5/5/e479.full.html\#\#otherarticles

This article, along with others on similar topics, appears in the following collection(s):

Autoimmune diseases

http://nn.neurology.org//cgi/collection/autoimmune_diseases Critical care

http://nn.neurology.org//cgi/collection/critical_care

Multiple sclerosis

http://nn.neurology.org//cgi/collection/multiple_sclerosis

Vasculitis

http://nn.neurology.org//cgi/collection/vasculitis

Information about reproducing this article in parts (figures,tables) or in its entirety can be found online at:

http://nn.neurology.org/misc/about.xhtml\#permissions

Information about ordering reprints can be found online:

http://nn.neurology.org/misc/addir.xhtml\#reprintsus

Neurol Neuroimmunol Neuroinflamm is an official journal of the American Academy of Neurology.

Published since April 2014, it is an open-access, online-only, continuous publication journal. Copyright

Copyright $\odot 2018$ The Author(s). Published by Wolters Kluwer Health, Inc. on behalf of the American

Academy of Neurology.. All rights reserved. Online ISSN: 2332-7812.

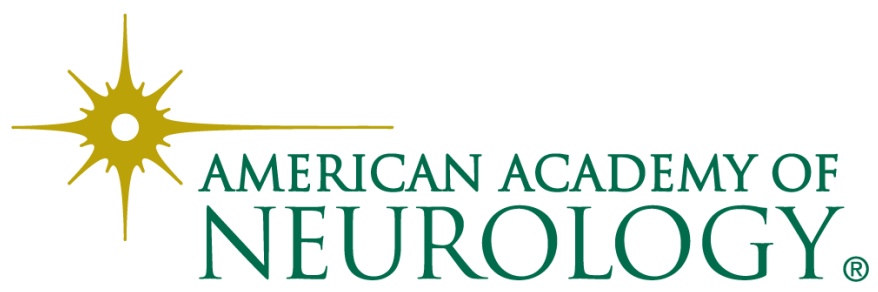

